\title{
VAT Gap Estimation And Influence of SELECTEd MethodS OF FINANCIAL ADMINISTRATION ON ITS REDUCTION
}

\author{
Lukáš Moravec $^{1}$, Jana Hinke ${ }^{2}$, Monika Borsiczká ${ }^{3}$
}

\begin{abstract}
The aim of this contribution is to quantify the influence of selected methods on elimination of value added tax gap in the Czech Republic within the researched period 2015-2016. To find a possible share of influence of the VAT control statement on tax fraud following priority methods were set: VAT control statement invitation, initiatives from pairing check reports, tax checking and procedures for doubt removal. By quantifying these methods, the values of theoretical benefits are measured and further compared with value added tax gap within the researched period. To set the VAT gap estimation a method was used that calculates via cleaning gross domestic product based on the database of national accounts. By using this approach it was found out that with the influence of selected methods of financial administration there was a tax gap decrease in 2015 by $5.54 \%$ and for 2016 by $4.00 \%$.
\end{abstract}

\section{Keywords}

VAT Gap, Tax Fraud, Tax Collection, Tax Administration, VAT Control Statement

\section{Introduction}

The most profitable tax income is the value added tax (in the Czech Republic with its $49 \%$ share between 2012 and 2016). The VAT GAP has become the indicator of tax frauds of VAT. Determining the VAP gap is one of the topics which has intracommunitary outreach and it is indisputable how important this issue is. Information about the growing tendency of VAT gap (growing number of tax evasion) is clear from e.g. tax gap analysis researched by CASE and many others. To quantify the VAT gap a wide range of methods is used, but the result is always deficit value of collected tax in relation to theoretical tax liability.

\footnotetext{
${ }^{1}$ Czech University of Life Sciences Prague, Faculty of Economics and Management, Department of Trade and Finance, Czech Republic. E-mail: lukasgm@gmail.com.

${ }^{2}$ Czech University of Life Sciences Prague, Faculty of Economics and Management, Department of Trade and Finance, Czech Republic. E-mail: hinke@ pef.czu.cz.

${ }^{3}$ Czech University of Life Sciences Prague, Faculty of Economics and Management, Department of Trade and Finance, Czech Republic. E-mail: borsiczka@pef.czu.cz.
} 
Single countries try to implement mechanisms to limit in a maximal possible way the loss on VAT and reach a decrease in the estimated gap. The amount of the VAT tax gap seems to be a fundamental problem in collecting taxes in the Czech Republic (but not only in the $\mathrm{CR}$ ). The importance of eliminating VAT evasion particularly in the Czech Republic is evident especially in the context of estimating the Czech Republic's tax losses due to tax competition among the EU member states and the spillover of profits into the so-called tax havens. As a result, the EU is dominated by political decisions that are not always in favour of the Czech Republic, i.e., by extreme pressures to eliminate tax competition and to reject a systemic solution to the problem of the VAT tax gap in the European Economic Area. The methods to reach the elimination of VAT evasion are mainly tax checking and recently control statement institute, which tax administration in the Czech Republic (or in cooperation with law enforcement agencies) has had since 2016.

Due to the absence of studies analysing the benefits, or, more precisely, the impact of selected methods on eliminating the gap in value added tax in the Czech Republic, this paper has been created. Its primary aim is to quantify the influence of selected tools on value added tax elimination in the Czech Republic within the researched period of 2015 and 2016.

The Introductory chapter is followed by the literature search presenting studies of authors dealing with these issues. The next chapter explains the research methods for possible replication of solutions. Another chapter interprets the authors' results and is immediately followed by the chapter on the critical determination of research limits. The Conclusion chapter summarizes the authors' findings and preconditions for further research.

\section{Theoretical Background}

Value added tax can be assessed as a tax which acts the same towards all entities and is neutral within the market environment. Products and services being the outcome of production in the area of a given country are subject to value added tax. This implies the unity and equality of conditions in terms of international trading preventing double taxation or differences in tax rate (Stř́lková and Široký, 2015). Countries with implemented system of value added tax have the highest yields from it within the fiscal set (Dobranschi and Nerudová, 2018). One of the benefits of the VAT which cannot be forgotten is the fact, that there is a certain two-sided supplier-purchaser check of proved supply in the way that the purchaser's interest is to lower their tax liability by using entry tax deduction, so in the posting of subjected accepted supply they check the values given by the supplier on the tax document. Disadvantages of VAT lie in the high requirements connected with the necessary administration, not only by its implementation within an area of a certain country, but also by the application that follows, meaning supply of tax liabilities of tax entities and the observance check from the side of the tax administration.

To prevent tax evasion in the area of GDP the following methods of financial administration are in service (Borsiczká, 2018): Searching, Local investigation, Electronic evidence of sales, Summary report, Domestic scheme of tax liability transfer, Bank accounts report, Procedures for doubt removal, Tax check, Tax enforcement, Pledge, Special way 
of securing tax, Securing orders, Tax Fraud Multidisciplinary Task Force, Institute of unreliable payer or Unreliable payers and since 2016 also Control Statement.

Control statement is an institute which serves the tax administration to make more effective check mechanisms within the agenda of value added tax (Semerád and Bartůňková, 2016). The aim of control statement is not only to add to carrousel frauds, but also to eliminate the risk of tax cut with common payers and to detect faults caused by for example inattentiveness when processing book-keeping agenda or ignorance of law and so prevent unintentional tax fraud. Examples of common unintentional mistakes in posted transactions are: discrepancies when billing advance payments, mistakes in tax document numbers, tax identification number, date of tax liability, etc. Semerád, Radvan and Bartůňková (2016) research the impact of Control Statement implementation on small and middle-sized companies. They state the size of sanctions resulting from this instrument as a negative factor. However, they do not deny its importance in the fight against frauds.

Yiallourou (2019) presents a careful overview about VAT gap measurement as the indicator of frauds. The aim of his article was to highlight not researched limitations of this measurement, specifically the absence of regional disparities. Generally, following methods of calculation of VAT gap can be mentioned (Koštáková and Zídková, 2015; Mihóková, Dráb and Kmetová, 2015):

* method of calculation based on tables on supply and usage - disadvantage is publishing of such data by Czech Statistical Office in five-year intervals,

* method WAR using tables on supply and usage and also information from tax return disadvantage is the presumption of knowledge of data from tax returns,

* method of "cleaning" the GDP,

* direct method calculating with random chosen sample of entities with following recalculation on the whole economy.

An alternative method of measuring the VAT gap in EU was introduced in their article by authors Nerudová and Dobranschi (2019) using the help of the stochastic tax frontier model. They use the Value Added Tax total tax liability as the input to estimate the optimal frontier of the Value Added Tax, as well as to predict technical inefficiency. The stochastic tax frontier approach allows to disentangle the Value Added Tax gap, which is time dependent, from the persistent Value Added Tax gap - which is country specific.

A range of authors investigate the dependence of VAT gap size on different factors. For example Majerová (2016) researches the dependence on three different variables: index of CPI corruption perception, pace of GDP growth and basic rate of VAT (using the method of regressive analysis in 2000-2011), or Zídková and Pavel (2016), who discovered that increasing the rate from VAT income to GDP causes decreasing the difference in VAT. Also, if the VAT standard rate and the difference between standard and lowered VAT rate increases, the VAT gap grows. The third result was that variable check share of household consumption on GDP increases the VAT gap. A scientific aim of the research by Kundeliene, Stankevicius and Kabasinskas (2016) was to assess the relationship of VAT gap with the structure of budget and macroeconomic indicators in the countries of the EU. 
None of the authors writes about the influence of checking methods of the tax administrator on the size of the value added tax. In respect to a recent implementation of Control statement in the Czech Republic the research of such influence is timely and in respect to the size of the gap very desirable.

\section{Research Methodology}

To find out a possible share of influence of Control Statement implementation on tax evasion priority tools have been set:

* summons for Control Statement,

* initiatives from pairing control statements,

* tax checks and procedures for doubt removal.

By quantifying these tools the values of theoretical benefit are found out and they are further compared with the VAT gap in the researched period 2015 and 2016.

To set the VAT gap for 2015 and 2016 the method of calculation by cleaning the gross domestic product (GDP) was applied while using database of national accounts published by the Czech Statistical Office, mainly for the reason of data accessibility for the researched period. While processing data, the authors used the calculation of the gap for 2004-2010, which was applied in her dissertation by Zídková $(2014$, a). The reason is an exact assessment of used data from national accounts, which are subject of the calculation.

For meaning survey of theoretical tax liability from the given theoretical tax base possible, it will define weighted tax rate with the help of the following formula:

$$
\text { Weighted rate }(\%)=\frac{\text { income VAT }}{\text { financial consumption }- \text { income VAT }} * 100
$$

For the calculation of the final consumption following data are used:

* about final consumption of households,

* governmental institutions and

* non-profit organisations, accessible from national accounts.

The sum for expenditures for collective consumption was then deduced from this sum. Information about sums of collected VAT incomes for the researched period was found in the published analysis of Financial Administration (Financial Administration, 2018, b). The theoretical size of the tax will be count in accordance with Zídková (2014) in the formula:

$$
\text { Theoretical tax liability }=\frac{\text { theoretical tax base } * \text { weighted tax rate }}{1+\text { weighted tax rate }} * 100
$$

Calculations, graphs and tables of researched outputs are processed in the Excel software. 


\section{Research Results}

\section{Proper assessment of VAT gap}

All mentioned data used to calculate VAT gap are the total with the date 13.2.2018. The aim of single phases of the calculation is setting the theoretical tax base to a following research of theoretical amount of tax liability with the VAT tax.

\section{GDP, national economy}

The amount of GDP comes out of statistics of national accounts published by Czech Statistical Office $(2018$, a), while for calculation the GDP in common prices is used. The gross domestic product for the whole national economy is reduced by the value of products and services of the export and increased by the import.

Table 1: Gross domestic product with the adjustment of import and export (in mil. CZK)

\begin{tabular}{|l|c|c|}
\hline Period & $\mathbf{2 0 1 5}$ & $\mathbf{2 0 1 6}$ \\
\hline GDP & $4,595,783$ & $4,773,240$ \\
\hline GDP after adjustment of import and export & $4,320,094$ & $4,416,037$ \\
\hline
\end{tabular}

Source: own processing according to: National accounts database: GDP expenditure method (Czech Statistical Office 2018, a)

To define the amounts of expenditures, where it is impossible in single sectors of economy to claim tax deduction, it is further necessary to deduce gross formation of capital of the whole national economy.

Table 2: Formation of gross fix capital (national economy, in mil. CZK)

\begin{tabular}{|l|c|c|}
\hline Period & $\mathbf{2 0 1 5}$ & $\mathbf{2 0 1 6}$ \\
\hline $\begin{array}{l}\text { Formation of fix capital after change of supplies } \\
\text { and net valuables acquisition }\end{array}$ & $1,284,787$ & $1,257,260$ \\
\hline
\end{tabular}

Source: own processing according to: National accounts database: GDP expenditure method (Czech Statistical Office 2018, a)

With single sectors and according to the accessibility of data the authors had to do their own calculation of data concerning purchase of fix tangible and intangible assets (total of new and used fix assets acquisition). The reason for it is the publication of data for 2016 first at the end of June 2018. The authors got such information in a telephone conversation with an office worker of the Czech Statistical Office responsible for Annual accounts of institutional sectors (Zbranek, 2018). Based on this statement the missing data were calculated with the help of average amounts of given items for the period 2010-2015. The calculation is shown in the following table. 
Table 3: Calculation of average amounts of acquisition of fix assets

\begin{tabular}{|l|c|c|c|c|}
\hline $\begin{array}{l}\text { Sale and transfer of used } \\
\text { fix assets (in mil. CZK) }\end{array}$ & NISID & $\begin{array}{c}\text { Financial } \\
\text { institutions }\end{array}$ & $\begin{array}{c}\text { Governmental } \\
\text { institutions }\end{array}$ & Households \\
\hline 2010 & 523 & 6,886 & 48,794 & 137,133 \\
\hline 2011 & 428 & 8,092 & 41,464 & 148,300 \\
\hline 2012 & 462 & 6,659 & 28,428 & 162,622 \\
\hline 2013 & 417 & 7,475 & 28,514 & 184,680 \\
\hline 2014 & 356 & 5,857 & 23,195 & 161,197 \\
\hline 2015 & 411 & 10,187 & 24,974 & 198,812 \\
\hline Average 2016 & $\mathbf{4 3 3}$ & $\mathbf{7 , 5 2 6}$ & $\mathbf{3 2 , 5 6 2}$ & $\mathbf{1 6 5 , 4 5 7}$ \\
\hline Net acquisition of fix assets 2016 & 4,982 & 32,455 & 158,823 & 211,922 \\
\hline $\begin{array}{l}\text { Net acquisition of fix assets }+ \\
\text { average of sales and transfer of } \\
\text { used fix assets }\end{array}$ & $\mathbf{5 , 4 1 5}$ & $\mathbf{3 9 , 9 8 1}$ & $\mathbf{1 9 1 , 3 8 5}$ & $\mathbf{3 7 7 , 3 7 9}$ \\
\hline
\end{tabular}

Source: own processing, 2018 (NISID = Non-profit institutions serving households)

Important influence of absence of such data (or their "substitution" by the average in the past periods) on the final result of VAT gap cannot be excluded.

\section{Non-profit institutions serving households}

One of the sectors where there are taken into account the amounts being not subject to tax deduction or tax supply exemption are non-profit institutions serving households. Intermediate consumption of these institutions enters into calculation (or the amount of expenditures which are consumed already during the production process), as well the acquisition of new and used fix assets, change of supplies and acquisition of valuables and intangible unproduced assets.

Table 4: Intermediate consumption and gross formation of capital (non-profit institutions, in mil. CZK)

\begin{tabular}{|l|c|c|}
\hline Period & $\mathbf{2 0 1 5}$ & $\mathbf{2 0 1 6}$ \\
\hline $\begin{array}{l}\text { Intermediate consumption + gross formation of capital after adjustment } \\
\text { (non-profit institutions) }\end{array}$ & 51,050 & 41,939 \\
\hline
\end{tabular}

Source: own processing according to: National accounts database: Timeline of sector accounts (Czech Statistical Office 2018, a)

\section{Financial institutions}

When researching the intermediate consumption of financial institutions the sum calculated by Zídková $(2014$, b) was kept the same, when $40 \%$ of the expenditures use the claim for tax deduction. Also, gross formation of the capital including acquisition of new and used 
fix assets, change of supplies, acquisition of valuables and intangible unproduced assets is considered in proportional height without a claim for deduction (60:40).

Table 5: Intermediate consumption and gross formation of capital (financial institutions, in mil. CZK)

\begin{tabular}{|l|c|c|}
\hline Period & $\mathbf{2 0 1 5}$ & $\mathbf{2 0 1 6}$ \\
\hline $\begin{array}{l}\text { Intermediate consumption + Gross formation of capital after adjustment } \\
\text { and setting of share without a claim for deduction (financial institutions) }\end{array}$ & 112,720 & 108,005 \\
\hline
\end{tabular}

Source: own processing according to: National accounts database: Timeline of sector accounts (Czech Statistical Office 2018, a)

\section{Governmental institutions}

The value of collective consumption expenditures is deduced from the sum total of intermediate consumption of governmental institutions and their purchase of new and used fix assets, change of supplies and acquisition of valuables and intangible unproduced assets.

Table 6: Intermediate consumption and gross formation of capital (governmental institutions in mil. CZK)

\begin{tabular}{|l|c|c|}
\hline Period & $\mathbf{2 0 1 5}$ & $\mathbf{2 0 1 6}$ \\
\hline $\begin{array}{l}\text { Intermediate consumption + gross formation of capital after adjustment } \\
\text { and deduction of collective consumption }\end{array}$ & 134,140 & 53,042 \\
\hline
\end{tabular}

Source: own processing according to: National accounts database: Timeline of sector accounts (Czech Statistical Office 2018, a)

\section{Households}

In the sector of households - the expenditures of residents abroad were taken into account and were deduced from the expenditures of non-residents in the Czech Republic. The sum of housing acquisition was deduced from the acquisition of new and used fix assets, change of supplies and acquisition of valuables and intangible unproduced assets (Czech Statistical Office 2018, b). After that the calculation of share of small business entities payers and non-payers of VAT tax was made.

Table 7: Analysis of individuals - active VAT payers

\begin{tabular}{|l|c|c|c|c|}
\hline & $\mathbf{2 0 1 5}$ & Share on total & $\mathbf{2 0 1 6}$ & Share on total \\
\hline Individuals - active VAT payers, domestic & 291,133 & 23.32 & 280,274 & 22.59 \\
\hline $\begin{array}{l}\text { Individuals - active businessmen handing } \\
\text { in personal income tax }\end{array}$ & 957,185 & 76.68 & 960,550 & 77.41 \\
\hline Individuals - total & $1,248,318$ & 100.00 & $1,240,824$ & 100.00 \\
\hline
\end{tabular}

Source: own processing according to: Data from the register of tax entities. (Financial administration 2019) 
Gross formation of the capital of businessmen - VAT non-payers was increased by the total expenditures for housing acquisition and then decreased by the production for own final usage of the household sector.

Table 8: Gross formation of the capital after adjustment (households, in mil. CZK)

\begin{tabular}{|l|c|c|}
\hline Period & $\mathbf{2 0 1 5}$ & $\mathbf{2 0 1 6}$ \\
\hline $\begin{array}{l}\text { Gross formation of the capital after adjustment of the expenditures of } \\
\text { non-/residents, acquisition of housing, exemption of share of VAT tax } \\
\text { payers and deduction of production for own usage }\end{array}$ & 119,681 & 98,861 \\
\hline
\end{tabular}

Source: own processing according to: National accounts database: Timeline of sector accounts (Czech Statistical Office 2018, a)

To make "detaxation", meaning survey of theoretical tax liability from the given theoretical tax base (or more precisely from the total sum including value added tax, which will be used for the total tax calculation) possible, it is desirable to define weighted tax rate.

For the calculation of the final consumption following data was used: about final consumption of households, governmental institutions and non-profit organisations, accessible from national accounts. The sum for expenditures for collective consumption was then deduced from this sum. Based on this data the calculation can be done in the following way (in mil. CZK):

$$
\begin{aligned}
& \text { Weighted rate } 2015(\text { Percent })=\frac{331836}{2619898-331836} * 100 \\
& \text { Weighted rate }_{2016}(\text { Percent })=\frac{349460}{2726411-349460}+100
\end{aligned}
$$

After calculation of the weighted tax rate it is further possible to count the theoretical size of the tax:

Table 9: Theoretical tax liability (in mil. CZK)

\begin{tabular}{|l|c|c|}
\hline Period & $\mathbf{2 0 1 5}$ & $\mathbf{2 0 1 6}$ \\
\hline Theoretical tax liability & 437,344 & 443,568 \\
\hline
\end{tabular}

Source: own processing, 2020

The tax gap estimation is calculated by deduction of really collected VAT tax incomes from theoretical tax liability. Percentage calculation below:

Table 10: Absolute and relative VAT gap (in mil. CZK, in \%)

\begin{tabular}{|l|c|c|}
\hline Period & $\mathbf{2 0 1 5}$ & $\mathbf{2 0 1 6}$ \\
\hline VAT gap (mil. CZK) & 105,508 & 94,108 \\
\hline VAT gap (Percent) & 24.12 & 21.22 \\
\hline
\end{tabular}

Source: own processing, 2020 


\section{Comparison of accessible studies and own estimation}

Accessible data dealing with tax gap were found to compare it with VAT gap estimation calculated by the authors. Outputs from the period 2012-2016, or 2015, from sources given below were used for the comparison. Single calculations use different methods for the survey. Also, the input data is a factor which can be approached in different ways. Consequently, it often changes within the flow of the years, depending on update of used data (authors could experience that within their own VAT gap estimation survey). Cause for the unprocessed update of gap estimation for the last periods can be the fact that complete data serving for calculation are published by the Czech Statistical Office from justifiable reasons in retrospect.

Table 11: Comparison of accessible VAT gap estimations

\begin{tabular}{|l|c|c|c|c|}
\hline \multirow{2}{*}{ SOURCE } & \multicolumn{2}{|c|}{2012} & \multicolumn{2}{c|}{2013} \\
\cline { 2 - 5 } & mil. CZK & Percent & mil. CZK & Percent \\
\hline Study CASE - Final report 2017 & 72,439 & 20.00 & 71,116 & 19.00 \\
\hline $\begin{array}{l}\text { NKÚ - Summary from the control } \\
\text { event 14/17 }\end{array}$ & 100,634 & 26.00 & 104,936 & 25.70 \\
\hline $\begin{array}{l}\text { Moravec et al. - calculation with the } \\
\text { help of form of supplies and usage }\end{array}$ & 115,557 & 28.70 & 118,445 & 28.05 \\
\hline Moravec et al. - GDP cleaning method & 65,369 & 16.26 & 69,034 & 16.07 \\
\hline $\begin{array}{l}\text { Stavjaňová - calculation with the help } \\
\text { of form of supplies and usage }\end{array}$ & 127,000 & 31.40 & - & - \\
\hline
\end{tabular}

Source: own processing in accordance with: CASE (2017), NKÚ (2017), Moravec, Hinke and Kaňka (2018), Stavjaňová (2014)

Table 12: Comparison of accessible VAT gap estimations (mil. CZK/\%) - part 2

\begin{tabular}{|l|c|c|c|c|c|c|}
\hline \multirow{2}{*}{ SOURCE } & \multicolumn{2}{|c|}{2014} & \multicolumn{2}{c|}{2015} & \multicolumn{2}{c|}{2016} \\
\cline { 2 - 7 } & mil. CZK & Percent & mil. CZK & Percent & mil. CZK & Percent \\
\hline $\begin{array}{l}\text { Study } \\
\text { CASE - Final report } \\
2017\end{array}$ & 63,697 & 17 & 66,669 & 16 & - & - \\
\hline $\begin{array}{l}\text { NKÚ - Summary from } \\
\text { the control event } \\
14 / 17\end{array}$ & - & - & - & - & - & - \\
\hline $\begin{array}{l}\text { Moravec et al. - } \\
\text { Calculation with the } \\
\text { help of form of supplies } \\
\text { and usage }\end{array}$ & 113,828 & 26.27 & - & - & - & - \\
\hline
\end{tabular}




\begin{tabular}{|l|c|c|c|c|c|c|}
\hline \multirow{2}{*}{ SOURCE } & \multicolumn{2}{|c|}{2014} & \multicolumn{2}{c|}{2015} & \multicolumn{2}{c|}{2016} \\
\cline { 2 - 7 } & mil. CZK & Percent & mil. CZK & Percent & mil. CZK & Percent \\
\hline $\begin{array}{l}\text { Moravec et al. - GDP } \\
\text { cleaning method }\end{array}$ & 60,524 & 13.77 & - & - & - & - \\
\hline $\begin{array}{l}\text { Stavjaňová - } \\
\text { Calculation with the } \\
\text { help of form of supplies } \\
\text { and usage }\end{array}$ & - & - & - & - & - & - \\
\hline $\begin{array}{l}\text { GDP cleaning method } \\
\text { calculated by authors }\end{array}$ & - & - & 105,508 & 24.12 & 94,108 & 21.22 \\
\hline
\end{tabular}

Source: own processing in accordance with: CASE (2017), NKÚ (2017), Moravec, Hinke and Kaňka (2018), Stavjaňová (2014)

The VAT gap estimation calculated by the authors for 2016 cannot be compared with other calculations, because relevant data for the researched period have not been published so far. The only comparable figure is given for 2015 by the study CASE, however the amounts defined by this source differ greatly from the amounts calculated by the authors. The main reason is possibly a different approach to input data and their subsequent usage for calculation.

\section{Relationship of the VAT gap and methods of financial administration against tax fraud}

When comparing VAT between 2015 and 2016 a decrease can be seen, which is from the point of view of the fight against tax fraud perceived positively.

To assess the benefits of methods of Financial Administration of the Czech Republic in the fight against tax fraud with VAT the authors first surveyed fiscal benefits of single methods: Summons from control statement, Initiatives from control statement, Tax checks and Procedures for doubt removal.

Sums concerning Summons from control statement and Initiatives from control statement were quantified by recalculation of the data provided by one financial office (specifically Financial Office for Olomouc Region) to the whole Czech Republic. Data for the selected region were applied on the Czech Republic with the help of a variable - Number of Summons and Initiatives, because it is perceived by the authors as a more precise indicator of theoretical fiscal effect than for example recalculation based on the number of payers. Based on the publicly accessible data of Financial Administration $(2018, b)$ additionally assessed taxes from Tax checks for VAT and also revenues from Procedures for doubt removal were found.

Considering these defined methods makes it possible to claim following fiscal benefits from the value added tax. 
Table 13: VAT revenues related to selected methods of financial administration (in thousand CZK)

\begin{tabular}{|l|c|c|}
\hline Method/Year & $\mathbf{2 0 1 5}$ & $\mathbf{2 0 1 6}$ \\
\hline Change of tax - Summons from control statement & 0 & 214,295 \\
\hline Change of tax - Initiatives from pairing control statement & 0 & 239,621 \\
\hline Additionally assessed taxes from Tax checks & $13,660,791$ & $12,454,914$ \\
\hline Revenue from Procedures for doubt removal & $10,564,998$ & $4,872,856$ \\
\hline
\end{tabular}

Source: change of tax - own calculation; additionally assessed taxes from tax check and revenue from procedures for doubt removal - Financial Administration $(2018, b)$

With the help of graphs shown below the shares of single methods on the overall fiscal benefit can be assessed. The benefit is the result of activity and acts of financial administration.

Figure 1: Share of selected methods on the overall change of tax in 2015

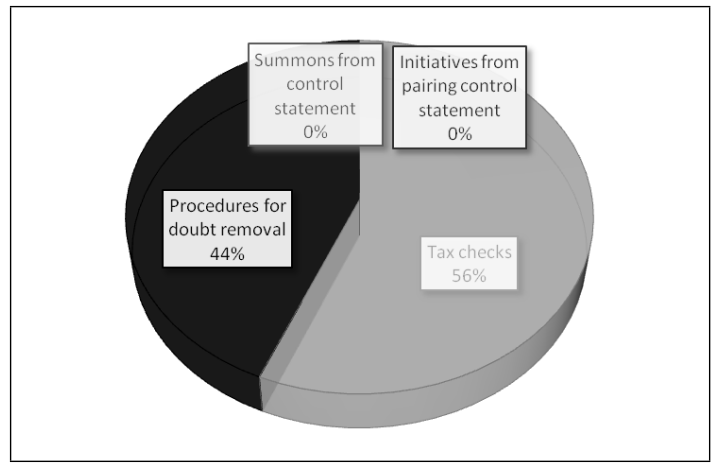

Source: own processing, 2020

Implementation of methods for investigating discrepancies from control statement proves first in outputs for 2016 due to start of control statement on 1.1.2016.

Figure 2: Share of selected methods on the overall change of VAT in 2016

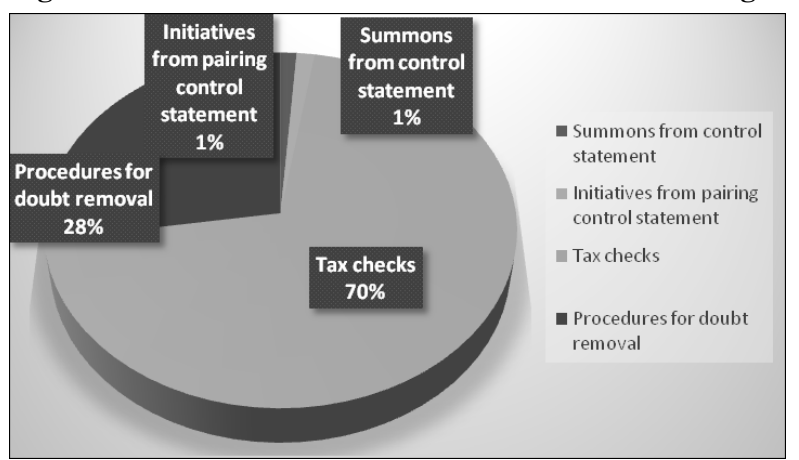

Source: own processing, 2020 
Overall revenue for the usage of selected methods is for 2016 lower in comparison with the previous year. It is caused by an overall decrease of revenue based on tax checks and procedures for doubt removal. Although a new institute of control statement was implemented, this tool has not a very high share on the overall fiscal benefit (in total only $2.56 \%$ ).

The following table sums up indicators found and concludes from them the size of VAT gap without fiscal benefits of financial administration.

Table 14: Summary table of VAT indicators for 2015 and 2016

\begin{tabular}{|l|c|c|c|c|}
\hline \multirow{2}{*}{ Indicator/Year } & \multicolumn{2}{|c|}{ 2015 } & \multicolumn{2}{c|}{ 2016 } \\
\cline { 2 - 5 } & mil. CZK & Percent & mil. CZK & Percent \\
\hline Theoretical tax liability for VAT & 437,344 & - & 443,568 & - \\
\hline Real collection VAT & 331,836 & - & 349,460 & - \\
\hline VAT gap with interventions & 105,508 & 24.12 & 94,108 & 21.22 \\
\hline $\begin{array}{l}\text { Share of Control Statement on real } \\
\text { collection }\end{array}$ & 0 & 0 & 454 & 0.13 \\
\hline $\begin{array}{l}\text { Share of Tax Checks and Procedures for } \\
\text { doubt removal on real collection }\end{array}$ & 24,226 & 7.3 & 17,328 & 4.96 \\
\hline $\begin{array}{l}\text { Share of selected methods on real } \\
\text { collection IN TOTAL }\end{array}$ & 24,226 & 7.3 & 17,782 & 5.09 \\
\hline $\begin{array}{l}\text { Real collection on VAT without fiscal } \\
\text { benefits of financial administration }\end{array}$ & 307,610 & - & 331,678 & - \\
\hline $\begin{array}{l}\text { VAT gap without the methods of financial } \\
\text { administration }\end{array}$ & $129,734 *$ & $29.66^{* *}$ & $111,890^{* * *}$ & $25.22 * *$ \\
\hline
\end{tabular}

Source: own processing; real collection: Data from tax collection Financial administration $(2018, a)$ Note: *(437 $344-307610)$, **\% from theoretical tax liability, ***(443 $568-331678)$

The table above shows first theoretical tax liability, then real collection according to data of Financial Administration (2018, a). Assuming that selected methods, which were subject of this article, were part of the real VAT collection, shares on real collection can be concluded. If the real collection is decreased by percentage share of selected methods on total real collection, we get the real VAT collection without fiscal benefits of financial administration. Subsequently, calculation of VAT gap follows, where fiscal benefits of single methods are not taken into consideration. The total VAT gap decrease can be seen in case when the input data about real incomes are considered incomes without change of tax based on Summons and Initiatives, without additionally assessed tax from Tax checks and without revenues from Procedures for doubt removal.

Shown data is calculated only on the level of formerly defined measurements against tax evasion. The authors are aware of the fact that financial and customs administration (and their instances) have a number of other tools which contribute to higher efficiency when 
eliminating tax evasion. However, it is in a practical way very difficult to reflect these tools as quantification of fiscal benefits considering the accessibility and system of data evidence.

Based on the facts above it is possible to indicate (assuming the limited data and own estimation) that due to the influence of selected methods of financial administration there was a tax gap reduction by $5.54 \%(29.66-24.12)$ for 2015 and by $4.00 \%(25.22-21.22)$ for 2016. Although the summary percent comparison shows a higher amount for 2015, in total a reduction of the value added tax gap was reached. This fact is proved by the comparison of gap estimation in years (variation 1 calculates with data without the use of financial administration methods, variation 2 is the real gap estimation, including all acts leading to tax fraud suppression).

\section{Figure 3: Comparison of the output of VAT gap in 2015 and $2016 \mathrm{~K}$ (in mil. CZK)}

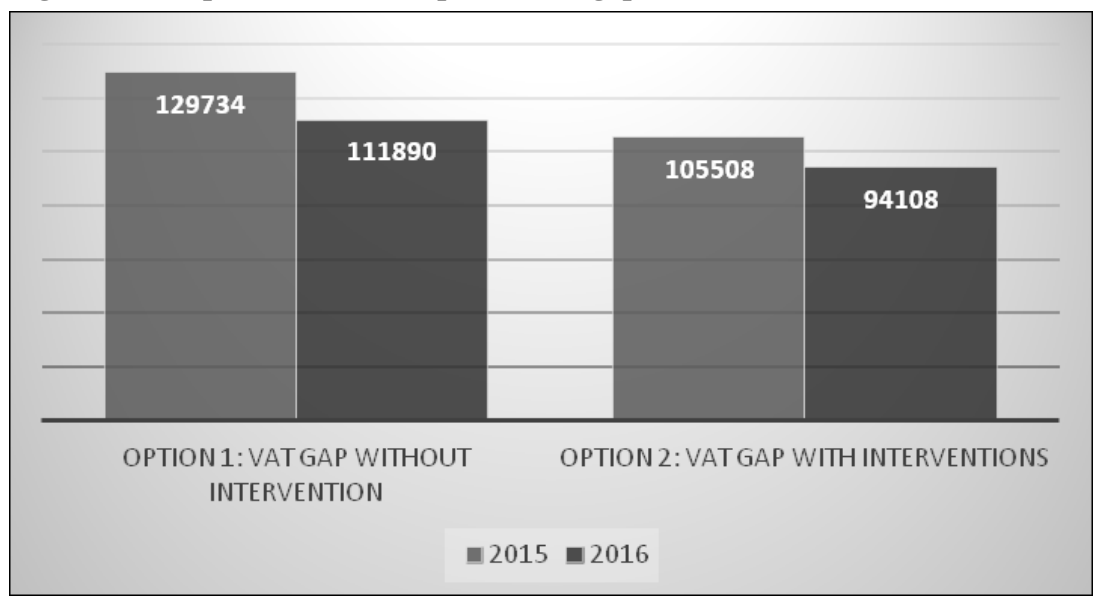

Source: own processing, 2020

With the variation 1 the VAT gap reduction is $4.44 \%$ (decrease from $29.66 \%$ to $25.22 \%$ ), variation 2 , that shows general gap estimation, reports a positive trend, meaning a tax gap decrease by $2.9 \%$ (decrease from $24.12 \%$ to $21.22 \%$ ).

The implementation of control statement according to shown output data did not in comparison with 2015 lead to an increase of fiscal benefit based on measurements ensuing from the usage of selected methods. However - the total collection in 2016 increased by $5.3 \%$ (from the amount 331,836 mil. CZK to 349,460 mil. CZK) and also a falling tendency of value added tax gap can be seen based on the estimation calculated.

Nevertheless, the expected benefit predicted in the reasoning report of the Parliament of the Czech Republic (PČR, 2014) in the form of a tax gap decrease by 5-10\% has not been reached so far. The assumption of the Parliament of the Czech Republic about the revenue from additionally collected value added tax for the initial evaluation possible period in the amount of 5-10 billion CZK (PČR, 2014) was fulfilled. 


\section{Limitation of Research}

Following influences could possibly lead to the collection increase or to VAT gap decrease: general increase of gross domestic product, suppression of fraud chain activities, whose parts were caught by financial administration due to control statement or necessity of restriction of the intended tax fraud from the side of tax entities with relation to the implementation of the control statement.

In connection with the calculations above it is possible to claim that the value ensuing from additionally assessed tax of tax checks does not have to be a very relevant indicator concerning benefits of control statements, because a great part of tax checks had been started before the implementation of control statements, which means that a simple act of quitting tax checks and recording relevant additionally assessed tax into the database does not picture corresponding benefit of the control statement. It is also possible to assume that a large part of complicated proceedings concerning chain frauds could have dated (regarding the start of control statement in 2016) their beginning of investigation for example to the middle of 2016. VAT chain frauds often have an intracommunitary overlap and cooperation in international information exchange can be long-term. As the given consideration implies, many proceedings (which would have had influence on recording, e.g. additionally assessed tax from tax checks) will enter with their numbers concerning VAT collection first into next periods.

Electronic evidence of sales, as a tool for suppression for tax losses, did not have with high probability important influence on VAT tax collection as for additionally assessed tax from tax checks. The system of electronic evidence of sales went through a complex formation, so as direct fiscal benefits cannot be considered only issued fines e.g. for an unregistered plant, etc. Electronic evidence has its indirect share on the general collection through sales that were not acknowledged in the past.

\section{Conclusion}

The study defines single methods of financial administration which serve to eliminate tax fraud on value added tax. By evaluating single shares of defined methods it was found that in 2016 the benefit of Summons and Initiatives was not striking. Final data underwent an annual comparison resulting in the summary of a decrease of revenue recorded with the help of all these methods.

Next, it was desirable to deal with evaluation with regard to the general collection on VAT. For this reason a VAT gap was estimated by the method of cleaning of gross domestic product and determining weighted tax rate. Results of VAT gap (105,508 mil. CZK in 2015 and 94,108 mil. CZK in 2016) were compared with already existing (accessible) studies. Furthermore, shares on real collection were ensued and real collection without fiscal benefits of financial administration was calculated. After that it was possible to calculate VAT gap regardless fiscal benefits of defined methods. By using this approach it was found out that with the influence of selected methods of financial administration there was a tax gap decrease in 2015 by $5.54 \%(29.66-24.12)$ and for 2016 by $4.00 \%$ 
(25.22 - 21.22). Although summary percentage comparison shows a higher number for 2015, generally there was a decrease in the value added tax gap in 2016.

It will be possible to assess the real influence of control statement with the time, within the following years. As the study uses data from 2016, being the year of implementation of the institute of control statement, a gradual increase of benefit of control statement can be expected as well as methods serving the detection of cases having impact on elimination of tax frauds.

\section{Acknowledgements}

This study consists of partial results of research project No. 2019B0010 - Czech Social System Fraud Rate Estimation and System Optimization Proposals, financially supported by the Internal Grant Agency (IGA) of Faculty of Economics and Management, CULS Prague.

\section{References}

Borsiczká, M. (2018). Estimation of fiscal effect of control report in selected region. Diploma Thesis, FBE CULS Prague.

CASE. (2017). Study and Reports on the VAT Gap in the EU-28 Member States: 2017 Final Report. Retrieved December 20, 2019, from https:/ec.europa.eu/taxation_customs/sites/ taxation/files/study_and_reports_on_the_vat_gap_2017.pdf.

Czech Statistical Office. (2018, a). National accounts database: GDP expenditure method, Time series of sector accounts. Retrieved December 20, 2019, from http://apl.czso.cz/pll/ rocenka/rocenkavyber.makroek_vydaj.

Czech Statistical Office. (2018, b.) Gross domestic product - Time series of quarterly account indicators. Retrieved June 1, 2020, from https://www.czso.cz/csu/czso/hdp_cr. Dobranschi, M., Nerudová, D. (2018). Tax Collision: The Effect of VAT and Excise Duties on the Retail Price of Unleaded Gasoline. Ekonomický časopis, 66/7, 643-664.

Financial administration. (2019). Data from the register of tax subjects. Retrieved June 12, 2019, from http://www.financnisprava.cz/cs/dane/analyzy-astatistiky/udaje-z-registru-danovych-subjektu.

Financial administration. (2018, a). Data from tax collection. Retrieved December 2, 2019, from http://www.financnisprava.cz/cs/dane/analyzy-a-statistiky/udaje-z-vyberu-dani.

Financial administration. (2018, b). Annual reports and activity information. Retrieved December 19, 2019, from http://www.financnisprv.cz/cs/financni-sprava-cr/vyrocni-zpravy-a-souvisejici-dokumenty/.

Koštáková, T., Zídková, H. (2015). VAT Gap in the Czech Republic and Slovak Republic. Ekonomický časopis, 63/7, 705-717.

Kundeliene, K., Stankevicius, E., Kabasinskas, A. (2016). Assessment of VAT GAP Relationship with Budget Structure and Macroeconomic Indicators: EU Countries Case. 21st International Scientific Conference on Smart and Efficient Economy - Preparation for the Future Innovative Economy. University of Technology, Brno, Czech Republic. 657-664. 
Majerová, I. (2016). The Impact of Some Variables on the VAT Gap in the Member States of the European Union Company. Oeconomia Copernicana, 7/3, 339-355.

Mihóková, L., Dráb, R., Kmetová, O. (2015). Comparison of Estimated VAT Gap in the Slovak Republic. Central European Conference on Finance and Economics (CEFE). Herlany, Slovakia. 428-438.

Moravec, L., Hinke, J., Kaňka, S. (2018). VAT Gap Estimation - Czech Republic Case Study. Politická ekonomie, 66/4, 450-472. DOI: 10.18267/j.polek.1212.

NKÚ: National Audit Office. (2018). Audit conclusion from the SAO audit no. 14/17. Retrieved December 10, 2019, from https://www.nku.cz/assets/konzavery/K14017.pdf.

Nerudová, D., Dobranschi, M. (2019). Alternative method to measure the VAT gap in the EU: Stochastic tax frontier model approach. PLOS ONE, 14/1.

Semerád, P., Radvan, M., Bartůňková, L. (2016). VAT Control Statement problematic aspects. 21st International Conference on Theoretical and Practical Aspects of Public Finance 2016. University of Economics, Prague, Czech Republic. 90-95.

Semerád, P., Bartůňková, L. (2016). VAT Control Statement as a Solution to Tax Evasion in the Czech Republic. 19th International Conference Enterprise and Competitive Environment (ECE). Mendel University, Brno, Czech Republic. 220: 417-423.

Stavjaňová, J. (2014). Value Added Tax Gap in the Czech Republic. Retrieved June 12, 2019, from https://acta.mendelu.cz/media/pdf/actaun_2014062061427.pdf.

Stř́lková, R., Široký, J. (2015). Changes in the VAT burden on expenses of selected households in the Czech Republic (2007-2013). 18th International Conference on Enterprise and the Competitive Environment. Czech Republic: Brno, Mendel University, pp 842-851.

Yiallourou, K. (2019). The Limitations of the VAT Gap Measurement. Ec Tax Review, 28/4, 196-210.

Zbranek, J. (2018). Telephone information on the annual accounts of institutional sectors. Zídková, H., Pavel, J. (2016). What Causes the VAT Gap? Ekonomický časopis, 64/9, 811-826.

Zídková, H. (2014, a). VAT gap analysis. Dissertation, University of Economics, Prague, Faculty of Finance and Accounting.

Zídková, H. (2014, b). Determinants of VAT GAP in EU. Prague Economic Papers, 23/4, 514-530. 